\title{
INTEGRATED USE OF NEOCHETINA BRUCHI AND ALTERNARIA EICHHORNIAE IN CONTROLLING WATER HYACINTH
}

KASNO, SUNJAYA, ASMARINA S.R. PUTRJ , OKKY S. DHARMAPUTRA and HER! S. HANDAYANI SEAMED BIOTROP, P.O. Box 116, Bogor 16001, Indonesia

\begin{abstract}
The study on the integrated use of the chevroned water hyacinth weevil (Neochetina bruchi Mustache) and the water hyacinth blight disease (Alternaria eichhorniae Nag Raj \& Ponnappa) in suppressing water hyacinth growth was carried out under field conditions at Situ Bagendit lake, Garut, West Java.

The objectives of this study were (I) to investigate whether the combined use of the two control agents produced a better effect in suppressing water hyacinth growth, (ii) to evaluate whether there is a change in oviposition and feeding habit of the chevroned water hyacinth weevil if the water hyacinth is seriously infected by $A$. eichhorniae, and (iii) to evaluate the progress of weevil establishment in the field.

The following results were obtained:

(1) The concentration of Tween 80 which did not interfere with spore germination was 3\%.

(2) There was no difference between distilled water and 1\% Potato Dextrose Broth (PDB) as a medium for fungal spores production.

(3) The combined use of chevroned water hyacinth weevil and the water hyacinth blight produces a better suppressing on water hyacinth growth.

(4) There was no significant effect of heavy infection by the water hyacinth blight on oviposition habit of chevroned water hyacinth weevil. Heavy fungal infection only affected feeding habit of the adult chevroned water hyacinth weevil.

(5) Establishment of the chevroned water hyacinth weevil is in progress at Situ Bagendit lake, Garut regency, West Java.
\end{abstract}

Key words: Indonesia/Biological corArollNeochetina bruchi/'Alternaria eichhomiaelEiahhomia crassi-pes/Establ ishment.

\section{INTRODUCTION}

\section{Background}

The water hyacinth (Eichhorniae crassipes [Mart.] Solm.) originated from Brazil and has spread out to many subtropical and tropical countries. The plant has been considered as a noxious weed in those countries. The water hyacinth is one of the most serious aquatic weeds in Indonesia (Soerjani et al. 1976; Tjitrosoedirdjo et al. 1993) as well as in other Southeast Asian countries such as Malaysia (Ismail 1994).

Recently, as a control tehnique, biological conntrol has received more attention. However, the objective is not to eradicate but to suppress the target weed population at a tolerable level. Biological control can be considered as the most important component of Integrated Pest Management (Mangoendihardjo 1995). Introduction 
of specific and potential natural enemies is the best technique for the control of exotic weeds (Andreas et al. 1976; Simmons 1970).

According to Nag Raj \& Ponnappa (1970) and Dharmaputra (1997), Alternaria eichhorniae is host specific to water hyacinth and monochoria. Learning from other countries, water hyacinth weevils have shown a partial control only to water hyacinth. The combined use of the two agents has produced very good results in India (Gopal, personal communication 1996). For this reason, the integrated use of weevil and pathogen in Indonesia was investigated.

\section{Objectives}

The objectives of this study were (1) to investigate the possible better effect of the integrated use ofNeochetina bruchi (Hustache) and Alternaria eichhorniae (Nag Raj \& Ponnappa) in suppressing the growth of water hyacinth; and (2) to examine the possible change of feeding and oviposition habit of the chevroned water hyacinth weevil caused by the heavy infestation of the fungus also, observations were made to monitor the establishment of the weevil in Situ Bagendit, Garut, West Java.

\section{METHODOLOGY}

\section{Rearing of the water hyacinth weevil}

The chevroned water hyacinth weevil (Neochetina bruchi Hustache) was introduced from Australia into Indonesia in 1995. After a series of tests under quarantine conditions at BIOTROP, the release permit was issued by the Government of Indonesia on June, 3 1996. The weevil was then mass reared on water hyacinth grown in concrete ponds at BIOTROP in Bogor.

Preparation of fungal culture and spore suspension

The fungus, $A$. eichhorniae used in this study was an isolate collected from Situ Bagendit lake at Garut regency, West Java. To obtain fungal spores for research purposes, the fungus was grown on rice husk yeast extract agar (RHYA) for at least 7 days at room temperature. Spore mass was first separated from their mycelia and medium by scrubing it using a fine brush. The spore mass was then filtered using a muslin cloth of about 50 micron pore size.

Experiment 1. The effect of sticking agent (Tween 80) on fungal spore germination

The effect of Tween 80 (polyoxyethylensorbitanmonooleate) in the aqua spore suspension on fungal spore germination was carried out under laboratory conditions. Various concentrations of Tween 80 i.e. 0, 1, 2, 3 and 4\% were evaluated. The spore concentration used was 1 × $10^{6}$ spores $/ \mathrm{ml}$. Spore germination was observed under 
the microsope (magnification $10 \times 10$ ) one hour after addition of Tween 80 . The optimum concentration with minimum side effect was used in further experiments.

\section{Experiment 2. Optimum spore concentration required to cause the disease (blight)}

Various concentrations of fungal spore i.e. $2.5 \times 10^{5}, 5.0 \times 10^{5}, 7.5 \times 10^{5}$ and $1.0 \times 10^{6}$ spores $/ \mathrm{ml}$ were evaluated under greenhouse conditions. Aside from spore suspension, two concentrations i.e. 2 and 3\% of Tween 80 as sticking agent, as well as 1\% Potato Dextrose Broth (PDB) and distilled water as carrying agents were also evaluated as to their ability to support the fungus to cause the disease in water hyacinth.

Inoculation of the spore suspension (1 ml/plant) was carried out on the water hyacinth surface using an atomizer at about $04.00 \mathrm{pm}$. Soon after inoculation, water hyacinth was placed in the gauze cage in the greenhouse. The cages were then covered with damp jute bags for 24 hours to create a suitable condition for spore germination and penetration.

The parameter used to evaluate the test was the damage severity of the water hyacinth plant due to fungal infectionn. The damage severity score was measured at 7 days after treatment. The scoring system was based on a 0 to 4 damage severity scale. The damage severity score of 0 means no infection, while score of 1, 2, 3 and

4 indicate $1-25 \%, 26-50 \%, 51-75 \%$ and more than $75 \%$ caused leaf damage or death, respectively.

\section{Experiment 3. Combined use of TV. bruchi weevil and spore suspension of A. eichhorniae to suppress water hyacinth growth under greenhouse conditions}

The target of this experiment was to obtain the optimum number of weevils in combination with spore suspension that would bring about a better effect in suppressing water hyacinth growth. The number of weevils released was $0,1,3$ and

5 pairs/plant, while concentrations of inoculated spore were $0,0.5,1.0$ and 1.5 times, respectively from the optimum concentration in Experiment 2. Water hyacinth with

6 leaves and $\pm 70 \mathrm{~g}$ wet weight was used in this experiment. The selected plants were then grown on plastic pots (1 plant/pot) containing tap water with mud at the bottom. To prevent the weevil from moving away, each pot was enclosed in transparant plastic cages with appropriate ventilation. Seven days after the weevils were released, spore suspension was used to inoculate the water hyacinth (3 replications/treatment). The treated plants were then placed in cages enclosed with damp jute bags for 24 hours.

Parameters used to evaluate the effect of the treatments were damage severity and biomass. The scoring scales as applied in experiment 2 was also applied in this experiment. 


\section{Experiment 4. Combined use of $\boldsymbol{N}$. bruchi weevil and spore suspension of $A$. eichhorniae to suppress water hyacinth growth under field conditions}

A procedure similar to Experiment 3 was set up under field conditions during dry and wet seasons. The number of released weevils was $0,1,3$ and 5 pairs/plant, while the concentration of spore suspensions for inoculation was 0 and $1 \times 10^{6}$ spores $/ \mathrm{ml} /$ plant. Three replications were set up for each treatment (3 plants/ replication) in two seasons. Selection of water hyacinth to nearly the same size was made prior to setting up the experiment. Observations on the effect of the two control agents were made at 14 and 21 days after weevils were released.

\section{Experiment 5. Possible change in adult weevil habit by selecting feeding and oviposition sites}

Normally, the weevil fed on the leaf surface of the water hyacinth and either the leaf tissue or petiole was used as sites for oviposition. An experiment was set up to investigate the possible effect of heavy fungal infection on the weevil in selecting sites for oviposition and feeding. Three pairs of adult weevil per plant were released, while the concentrations of inoculated spore suspension were 0 and $1 \times 10^{6}$ spore $/ \mathrm{ml} /$ plant. Five replications were set up for each treatment. An observation was done 14 days after weevils were released. Parameters used to measure the possible effect were the number of feeding scars and eggs on healthy and heavily infected water hyacinth.

\section{Experiment 6. Monitoring of weevil establishment in Situ Bagendit of Garut regency, West Java}

N. bruchii was released in Situ Bagendit lake on August, 281996 at 3 points. The number of weevils released at the first, second and third point was 75, 120 and 192 pairs respectively. Release was repeated on October, 16 1977. One hundred and sixty pairs of weevil were released in the center of the lake. Monitoring in the first year was done to record the dispersion of weevil from the initial point. Further monitoring in the second year was done to record the presence of weevil and feeding scars. Therefore, 10 samples for $0.5 \mathrm{~m} \mathrm{x} 0.5 \mathrm{~m}$ of water hyacinth showing feeding scars were collected.

\section{RESULTS AND DISCUSSION}

\section{Experiment 1. The effect of Tween 80 on fungal spore}

\section{germination}

Under field conditions, rain fall as well as wind may cause fungal spores fail to penetrate into the leaf surface before germination. Tween 80 may help spores to fix 
on the leaf surface for a certain period of time to avoid possible dispersal of spores due to rain fall and blowing wind. However, Tween 80 may cause reduction in spore germination. Such agents are often necessary to disperse fungal spores within a formulation and to support the spread and adherence of spores on the plant surface (Mitchell 1988). The use of certain concentrations of such agents may influence spore germination (Daigle \& Cotty 1991).

A test to evaluate the possible negative effect of Tween 80 on spore germination was made using $0,1,2,3$ and $4 \%$ concentrations. However, there was no significant difference in spore germination. The percentages of spore germination at concentrations of $0,1,2,3$ and $4 \%$ of Tween 80 were 96, 95, 94, 93 and 92, respectively. Considering the cost of Tween 80, a 2 and 3\% concentrations was selected.

\section{Experiment 2. Optimum spore concentration required to cause a disease (blight)}

Based on statistical analysis, the effect of spore and Tween 80 concentrations gave very significant differences to the severity score of water hyacinth leaves, while the effect of media was not significantly different (Appendix 1). The severity score on leaves when measured 7 days after treatment tended to increase with the increase of spore concentration. At spore concentrations of $7.5 \times 10^{5}$ and $1 \times 10^{6} / \mathrm{ml}$, the damage severity score was not different, i.e. 3.5 (Table 1). The damage severity score on leaves increased with increase of Tween 80 concentration. The scores for 0, 2 and 3\% Tween 80 concentration were 3.0, 3.1 and 3.7, respectively (Table 2). The use of 1\% PDB did not show a significant difference in the damage severity score when compared to distilled water as a medium (Table 2). Aqueous spore suspensions containing about $1.0 \times 10^{6}$ spores $/ \mathrm{ml}$ and $3 \%$ Tween 80 was selected for further experiments.

Table 1 . The effect of $A$. eichhomiae spore concentration, Tween 80 concentration and type of media on the severity score of water hyacinth

\begin{tabular}{cc} 
Treatment & Scoring \\
\hline Spore concentration $(/ \mathrm{ml})$ & \\
$2.5 \times 10^{\prime}$ & $2.8 \mathrm{~b}$ \\
$5.0 \times 10^{5}$ & $3.3 \mathrm{ab}$ \\
$7.5 \times 10^{\prime}$ & $3.5 \mathrm{a}$ \\
$1.0 \times 10^{6}$ & $3.5 \mathrm{a}$ \\
Tween 80 concentration $(\%)$ & \\
0 & $3.0 \mathrm{c}$ \\
2 & $3.1 \mathrm{c}$ \\
Type of media & $3.7 \mathrm{~d}$ \\
Distilled water & \\
$1 \%$ PD & $3.3 \mathrm{e}$ \\
\hline
\end{tabular}

Numbers followed by the same letter do not differ significantly according to DMRT at 95\% confidence level. 
According to Daigle \& Cotty (1991) addition of 1\% PDB to each surfactant concentration increased spore germination capability compared to surfactant or 1\% PDB alone. In this experiment spore germination with 1\% PDB was not observed. The result showed that there was no difference in the damage severity score between distilled water and 1\% PDB as the medium, and the use of 1\% PDB was discontinued.

\section{Experiment 3. Combined use of $\boldsymbol{N}$. bruchi weevil and spore suspension of $A$. eichhorniae to suppress water hyacinth growth under greenhouse conditions}

Based on statistical analysis the variation in number of adult weevil showed a significantly different effect on the damage severity score of water hyacinth leaves caused by the presence of the pathogen, weevils and their combination when measured at 14 days and 21 days after weevil release (Appendices 2 and 3). The damage severity score at 21 days after weevil release was higher than at 14 days for all treatments (Tables 2 and 3 ).

The damage severity score of water hyacinth leaves increased with the increase of weevil numbers and spore concentrations. The damage severity score due to pathogen infection was lower than that caused by weevil infestation. Nevertheless, the damage severity score caused by the combination of the two agents was higher than that caused by each agent (Table 3).

The damage severity score of combination between spore concentrations of $1.0 \times 10^{6}$ and $1.5 \times 10^{6} / \mathrm{ml}$; and between weevil numbers of 3 and 5 pairs were not significantly different (Tables $2^{\mathrm{v}}$ and 3 ). These facts indicated that the optimum combination in suppressing about 70 gram size of water hyacinth growth under greenhouse conditions was $1.0 \times 10^{6}$ spores $/ \mathrm{ml}$ and 3 pairs of adult weevil.

There was an indication of faster infection of pathogen on undamaged leaf tissue of water hyacinth if compared to the injured one. In other case, there was an indication of feeding preference of the adult weevil on the healthy tissue rather than on infected leaf tissue of water hyacinth.

Table 2. The effect of adult $N$. bruchi and $A$. eichhorniae spore concentration on the damage severity score of water hyacinth leaves due to pathogen, weevil and their combination at 14 days after weevil release

\begin{tabular}{lcccc}
\hline \multicolumn{5}{c}{ Damage severity score } \\
\hline $\begin{array}{c}\text { Spore cone. } \\
(/ \mathrm{ml})\end{array}$ & Pathogen & $\begin{array}{c}\text { No. of weevils } \\
\text { (pairs) }\end{array}$ & Weevil & Combination \\
\hline 0 & $0 \mathrm{a}$ & 0 & $0 \mathrm{~d}$ & $0 \mathrm{~h}$ \\
$5.0 \times 10^{\mathrm{s}}$ & $2.4 \mathrm{~b}$ & 1 & $1.8 \mathrm{e}$ & $2.5 \mathrm{i}$ \\
$1.0 \times 10^{\prime}$ & $2.7 \mathrm{be}$ & 3 & $2.9 \mathrm{f}$ & $3.7 \mathrm{~J}$ \\
$1.5 \times 10^{\prime}$ & $2.9 \mathrm{c}$ & 5 & $3.8 \mathrm{~g}$ & $3-9 \mathrm{~J}$ \\
\hline
\end{tabular}

Numbers followed by the same letter do not differ significantly according to DMRT at 95\% confidence level. 
Integrated use ofNeochetina bruchi and Alternaria eichhomiae - Kasno et al.

Table 3. The effect of adult $N$. bruchi and A. eichhomiae spore concentration on the damage severity score of water hyacinth leaves due to pathogen, weevil and their combination at 21 days after weevil release

\begin{tabular}{lcccc}
\hline \multicolumn{5}{c}{ Damage severity score } \\
\hline $\begin{array}{c}\text { Spore cone. } \\
(/ \mathrm{ml})\end{array}$ & Pathogen & $\begin{array}{c}\text { No. of weevils } \\
\text { (pairs) }\end{array}$ & Weevil & Combination \\
\hline 0 & $0 \mathrm{a}$ & 0 & $0 \mathrm{e}$ & $0 \mathrm{i}$ \\
$5.0 \times 10^{\prime}$ & $2.9 \mathrm{~b}$ & 1 & $2.7 \mathrm{f}$ & $2.8 \mathrm{~J}$ \\
$1.0 \times 10^{6}$ & $3.3 \mathrm{~cd}$ & 3 & $3.6 \mathrm{~g}$ & $4.0 \mathrm{k}$ \\
$1 . \mathrm{S}^{6}$ & $3.4 \mathrm{~d}$ & 5 & $3.9 \mathrm{~h}$ & $4.0 \mathrm{k}$
\end{tabular}

Numbers followed by the same letter do not differ significantly according to DMRT at 95\% confidence level.

Experiment 4. Combined use of $N$. bruchi weevil and spore suspension of $A$. eichhomiae to suppress water hyacinth growth under field conditions

\section{a. Dry season}

Based on statistical analysis, the variation in number of adult weevils showed a significantly different effect on the damage severity score of water hyacinth leaves caused by the presence of the weevils and combined use of the two agents when measured at 14 days and 21 days after weevil release (Appendices 4 and 5). The damage severity score at 21 days after weevil release was higher than at 14 days for all treatments (Table 4).

\section{b. Wet season}

Based on statistical analysis, the number of adult weevils showed a significantly different effect on the damage severity score of water hyacinth leaves caused by the presence of the weevils and combination of the two agents when measured at 14 days and 21 days after weevil release (Appendices 6 and 7). The damage severity score at 21 days after weevil release was higher than at 14 days for all treatments (Table 5).

The damage severity score either due to weevil, pathogen or their combination during wet season (Table 5) was lower than that during the dry season (Table 4). During the wet season the higher water nutrient content may provide better growth to water hyacinth plant, therefore the plant may be more resistant to the two suppressing agents.

Tables 4 and 5 show that the damage severity score due to combined use of the two agents, between 3 and 5 pairs of adult weevils was significantly different. This result differed from the result in Experiment 3. The different result in this experiment was assumed due to the difference in the number of plants for each 
replication. One plant was used in Experiment 3, while 3 plants were used in this experiment.

Charudattan et al. (1976) reported that infection of plants inoculated with Acremonium zonatum was more severe in the presence of $N$. eichhorniae. Sanders et al. (1982) also reported that in the Panama Canal a positive correlation exists between $A$. zonatum and $N$. eichhorniae.

Table 4. The effect of adult $N$. bruchi and $A$. eichhorniae spore concentration on the damage severity score of water hyacinth leaves due to pathogen, weevil and their combination at 14 and 21 days after weevil release during dry season

\begin{tabular}{|c|c|c|c|c|c|c|c|}
\hline \multicolumn{8}{|c|}{ Damage severity score } \\
\hline \multicolumn{3}{|c|}{ Pathogen } & \multicolumn{3}{|c|}{ Weevil } & \multicolumn{2}{|c|}{ Combination } \\
\hline $\begin{array}{l}\text { Spore } \\
\text { cone, } \\
(/ \mathrm{ml})\end{array}$ & 14 days & 21 days & $\begin{array}{l}\text { No. of } \\
\text { weevil, } \\
\text { (pairs) }\end{array}$ & 14 days & 21 days & 14 days & 21 days \\
\hline $\begin{array}{l}0 \\
1.0 x l \\
0^{6}\end{array}$ & $0 \quad$ a $2.7 b$ & 0 a $3.4 \mathrm{c}$ & $\begin{array}{lll}0 & 1 & 3 \\
5 & \end{array}$ & $\begin{array}{l}0 \mathrm{~d} 1.9 \mathrm{e} \\
2.4 \mathrm{f} 3.4 \mathrm{~g}\end{array}$ & $\begin{array}{l}0 \mathrm{~d} 2.3 \mathrm{f} \\
2.9 \mathrm{~g} 3.6 \mathrm{~h}\end{array}$ & $\begin{array}{lrl}0 & \text { i } 2.9 j \mathrm{jk} \\
3.3 \mathrm{kl} 3.61\end{array}$ & $\begin{array}{l}0 \text { i } 3.4 \mathrm{kl} \\
3.81 \mathrm{~m} 4.0 \mathrm{n}\end{array}$ \\
\hline
\end{tabular}

Numbers followed by the same letter do not differ significantly according to DMRT at 95\% confidence level.

Table 5. The effect of adult $N$. bruchi and A. eichhorniae spore concentration on the damage severity score of water hyacinth leaves due to pathogen, weevil and their combination at 14 and 21 days after weevil release during wet season

\begin{tabular}{|c|c|c|c|c|c|c|c|}
\hline \multicolumn{8}{|c|}{ Damage severity score } \\
\hline \multicolumn{3}{|c|}{ Pathogen } & \multicolumn{3}{|c|}{ Weevil } & \multicolumn{2}{|c|}{ Combination } \\
\hline $\begin{array}{l}\text { Spore } \\
\text { cone, } \\
(/ \mathrm{ml})\end{array}$ & 14 days & 21 days & $\begin{array}{l}\text { No. of } \\
\text { weevil } \\
\text { (pairs) }\end{array}$ & 14 days & 21 days & 14 days & 21 days \\
\hline $\begin{array}{ll}0 & 1.0 \\
\times 10^{6}\end{array}$ & 0 a 2.3b & 0 a 3.1c & $\begin{array}{ll}0 & 1 \\
3 & 5\end{array}$ & $\begin{array}{l}0 \mathrm{~d} 1.3 \mathrm{e} \\
2.3 \mathrm{~g} 3.2 \mathrm{i}\end{array}$ & \begin{tabular}{|l|l}
$0 \mathrm{~d} 2.8 \mathrm{f}$ \\
$2.9 \mathrm{~h} 3.6 \mathrm{~J}$
\end{tabular} & $\begin{array}{l}0 \quad \mathrm{k} 2.81 \\
3.3 \mathrm{~m} 3.5 \mathrm{~m}\end{array}$ & $\begin{array}{l}0 \mathrm{k} 3.3 \mathrm{~m} \\
3.8 \mathrm{n} 4.0 \mathrm{o}\end{array}$ \\
\hline
\end{tabular}

Numbers followed by the same letter do not differ significantly according to DMRT at 95\% confidence level.

The change of water hyacinth wet weight at 21 days after weevil release in each treatment is presented in Figure 1. The results show that the increase of adult weevils and concentration of spore pathogen reduced the increment of wet weight. It means that both water hyacinth control agents could suppress the growth of water hyacinth in the field. 


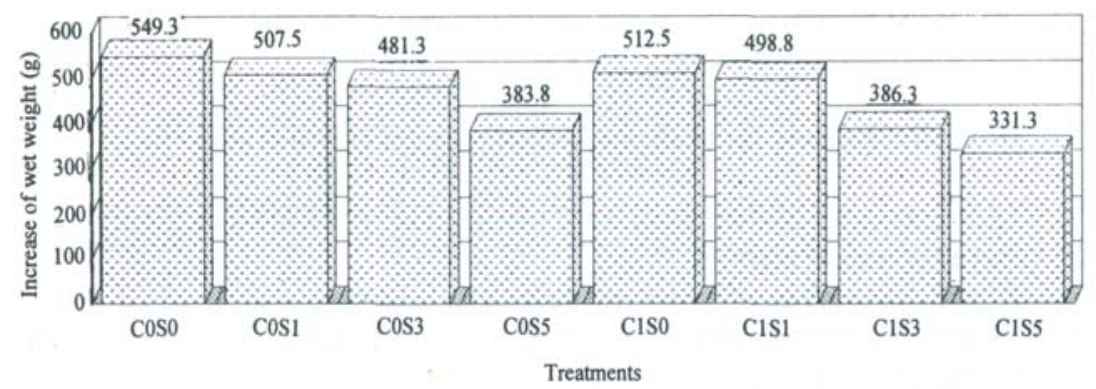

Figure 1 . The change of water hyacinth wet weight at 21 days after weevil release in each treatment. $\mathrm{C}=$ spore concentrations $(/ \mathrm{ml}) \quad \mathrm{S}=$ adult weevils (pairs)

$\left(1.0 \times 10^{6} \mathrm{spore} / \mathrm{ml}\right) \quad 0,1,3,5=$ number of pairs

Based on statistical analysis, number of adult weevils and concentration of pathogen spore caused very significantly different effect on the change of water hyacinth wet weight (Appendix 8).

Conway et al. (1978) reported that pathogen (Cercospora rodmanii) could influence the growth of water hyacinth and reduce the biomass. According to Galbraith (1987) Acremonium zonatum caused extensive infection of individual leaves of water hyacinth, but the whole plant survived since disease development did not keep up with the production of new leaves.

\section{Experiment 5. Possible change of adult weevil habit in selecting feeding and oviposition sites}

Figure 2 shows that the pathogen infection on water hyacinth did not reduce the production of weevil eggs. Weevils preferred to put their eggs on the petiole than on the leaf. So the infection of pathogen did not affect the oviposition behavior of weevil.

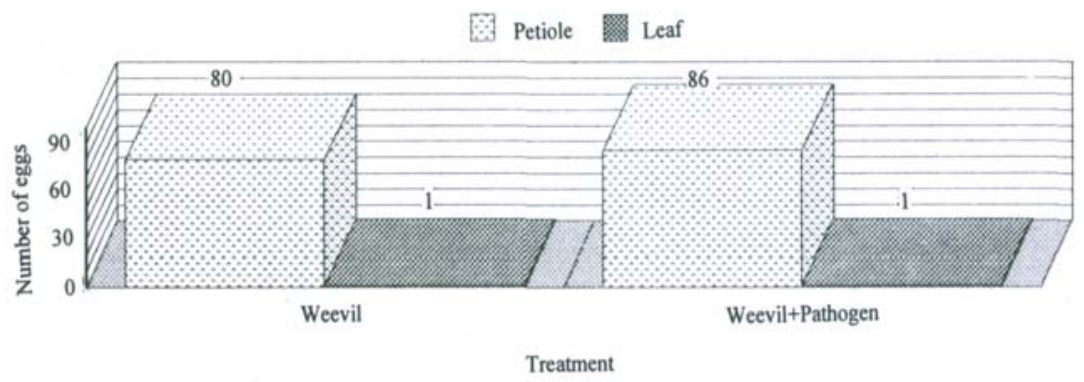

Figure 2. Distribution of $N$. bruchi oviposition sites. 


\section{Experiment 6. Monitoring of weevil establishment in Situ Bagendit, regency of Garut, West Java}

Generally, the steps for biological control program of weeds are as follows:

1. To determine the conformity of weed species to be controlled biologically.

2. Survey of natural enemies.

3. To study the ecology of weeds and their natural enemies.

4. To study the host specificity of natural enemies to secure that they could not become pest in the control area.

5. To introduce/release and establish natural enemies in the control area.

6. Evaluation.

One of the biological control program steps was to release TV. bruchi. It has been done and it is establishing now. Monitoring was carried out after weevils were released to investigate the difference that may occur in the field (Kasno 1989).

Monitoring was done at 2, 4 and 10 months after weevils were released indicating that the feeding symptom was found at distances of $\pm 45 \mathrm{~m}, \pm$ $250 \mathrm{~m}$ and $\pm 2 \mathrm{~km}$, respectively, from the initial point of release. However, no symptoms of attack were found on plantation crops surrounding the lake.

Tables 6 and 7 show the existence of adult weevils, eggs, larvae and pupae at 15 and 16 months after the weevils were released.

Population of adult weevils at 16 months after weevils were released was higher than at 15 months, i.e. from 0.8 to 1.4 insects per $0.5 \times 0.5 \mathrm{~m}$ area. Larvae and pupae were not found at 15 months after weevils were released. However, 16 months after the release larvae were also not found, but a small number of pupae were found i.e. 0.4. The number of eggs increased from 5.4 to 9.1. The average of leaf scars per second youngest leaf also increased, i.e. from 13.9 to 17.4 .

Generally, it could be concluded that TV. bruchi weevil was still in the process of establishment, since the number of adult weevils, eggs, larvae, pupae and other parameters increased. 
Integrated use of Neochetina bruchi and Alternaria eichhorniae - Kasno et al.

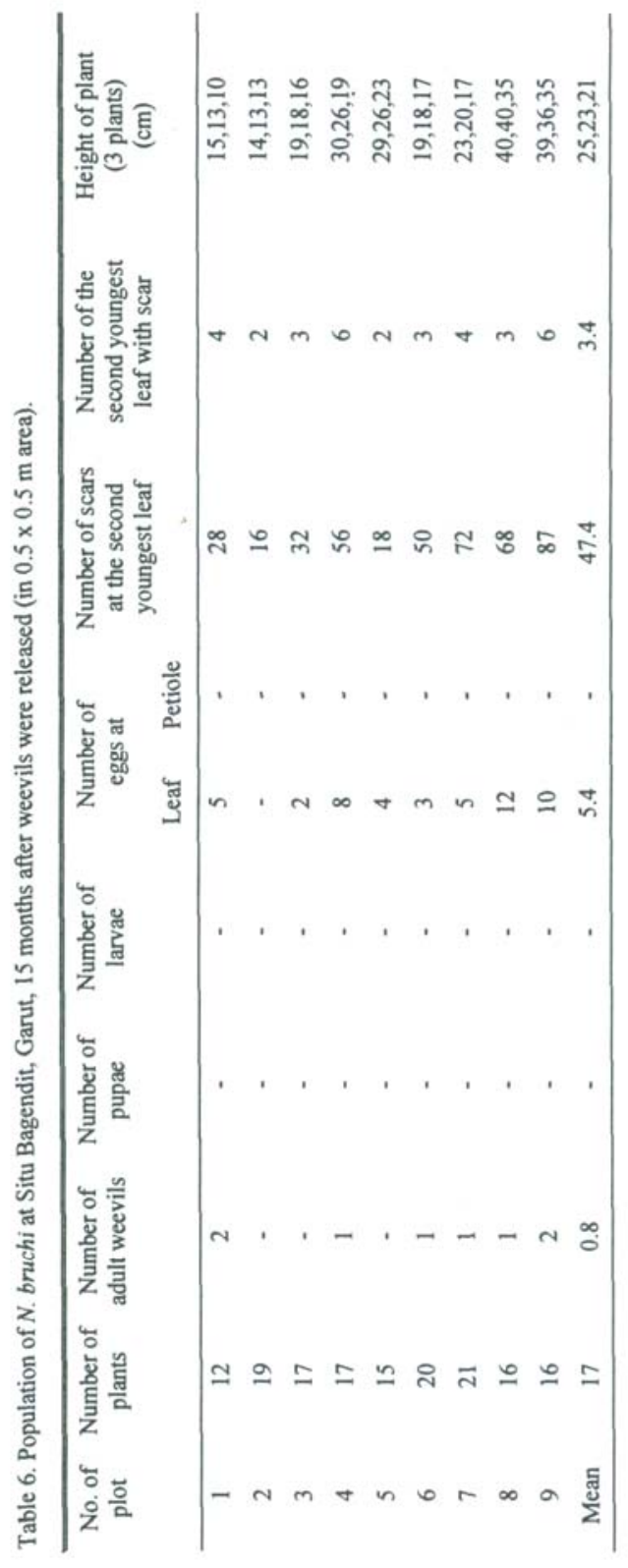


BIOTROPIA No. 13, 1999

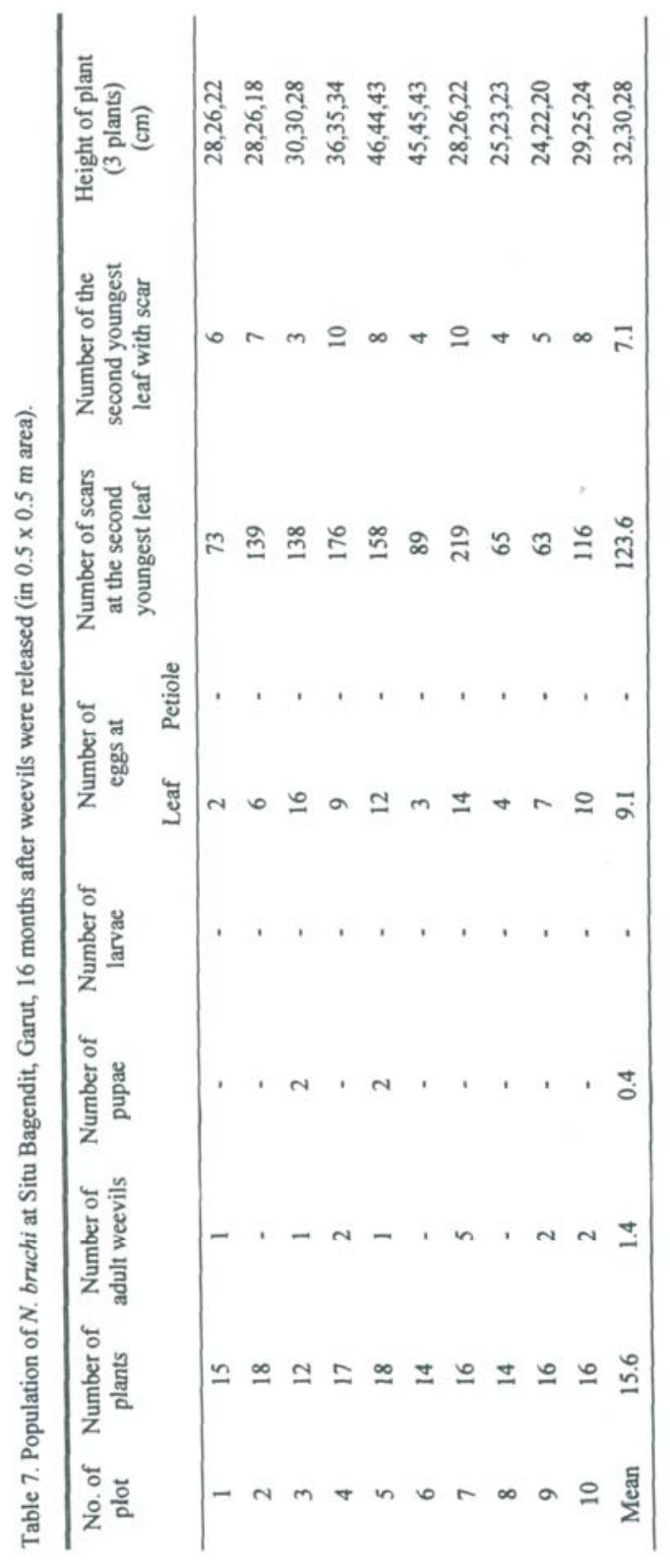


Integrated use ofNeochetina bruchi and Altemaria eichhorniae - Kasno et al.

\section{CONCLUSIONS}

1. The integrated use of $N$. bruchi and $A$. eichhorniae as a controlling agent ofwater hyacinth caused a better suppressing of water hyacinth and its growth rather than using the agents separately.

2. The infection of A. eichhorniae on water hyacinth leaf did not change the oviposition site of TV. bruchi.

3. N. bruchi prefers to feed on intact than on the infected leaf tissue.

4. The damage severity score from all treatments increased through the time.

5. Establishment of N. bruchi in Situ Bagendit lake, West Java is still in progress.

\section{ACKNOWLEDGMENT}

The authors would like to express our sincere thanks to the Department of Higher Education, Ministry of Education and Culture for the financial support, and to the Plant Quarantine Department, Ministry of Agriculture for the release permit of $N$. bruchi.

\section{REFERENCES}

ANDREAS, L.A., C.J. DA vis, P. HARRIS \& A.J. WHAPSHERE. 1976. Biological control of weeds. In C.B.

Huffaker \& P.S. Messenger (eds.). Theory and practice of biological control. Academic Press.

New

York.

BASHIR, O.M. 1984. The establishment and distribution of natural enemy of water hyacinth released in Sudan. Tropical Pest Management 30(3): 320-323.

CHARUDATTAN, R., T.E. FREEMAN \& K.E. CONWAY. 1976. Progress in the use of plant pathogens as biological control for aquatic weeds. Misc. Pap. A-77-3. US Army Engineer Waterways Exp. Stn, Vickbury. Miss.

CONWAY, K.E., T.E. FREEMAN \& R. CHARUDATTAN. 1978. Development of Cercospora rodmanii as a biological control for Eichhorniae crassipes. Proc. EWRS 5* Symp. On Aquat. Weeds. PO Box 14 ,

Wageningen, The Netherlands, p. 225-230.

DAIGLE, D.J. \& P.J. COTTY. 1991. Factors that influence germination and mycoherbicidal activity of Alternaria cassiae. Weed Tech. 5: 82-86.

DHARMAPUTRA, O.S. 1997. Pathogenicity test of Altemaria eichhorniae isolated from water hyacinth. SEAMEO BIOTROP. Internal report.

GALBRAITH, J.C. 1987. The pathogenicity of an Australian isolate of Acremonium zonatum to water hyacinth and its relationship with the biological control agent, Neochetina eichhorniae. Aust. J. Agric. Res. 38:219-229.

ISMAIL, M.A. 1994. Biological control efforts towards management of some common weeds in Malaysia. Proc. Symp. Biology and Management of Weeds and 14* Tropical Weed Science Society

Conference. SEAMEO BIOTROP. Bogor.

KASNO. 1989. Pengantar umum pengendalian gulma secara hayati. Kumpulan materi kuliah Pendidikan

dan Pelatihan Pengelolaan Gulma Proyek P2TP. Direktorat Jenderal Perkebunan, Bogor, 6

Nopember - 2 Desember 1989. SEAMEO BIOTROP.

MANGOENDiHARDJO, S. 1995. Pengendalian Hayati, Komponen Utama Pengelolaan Jazad Pengganggu (Biological control the main component of integrated pest management). Pidato pengukuhan Guru

Besar. Universitas Gadjah Mada, 22 Maret 1995, Yogyakarta. 26 p. 
BIOTROPIA No. 13, 1999

MITCHELL, J.K. 1988. Gibbago trianthema, a recently described hyphomycete with bioherbicide potential for control of horse purslane (Trianthema portulacastrum). Plant Dis. 72: 354-355.

NAG RAJ, T.R. \& K.M. PONNAPPA. 1970. Blight of water hyacinth by Alternaria eichhorniae sp. Nov.

Trans. Br. Mycol. Soc. 55(1): 123-130.

SANDERS, D.R., R.F. THERIOT \& E.A. THERIOT. 1982. Organisms impacting water hyacinth in the

Panama Canal. Misc. Pap. A-82-1, US Army Engineer Waterways Exp. Stn, Vicksbury, Miss.

SIMMONS, F.J. 1970. Biological control. Sompong Press, Bangkok. 12 p.

SOERJANI, M. el al. 1976. Proc. of the Southeast Asian Workshop on Aquatic Weeds. SEAMEO

BIOTROP. Bogor. 45 p.

TJTROSOEDIRDJO, S., KASNO \& SUNJAYA. 1993. Notes on the management of water hyacinth in Rawa

Pening lake: 1990-1991. In Proceedings of Integrated Pest Management Control Component.

BIOTROP Special Pub. No. 50: 147-155. 
Integrated use of Neochetina bnichi and Alternaria eichhorniae - Kasno et al.

Appendix 1. Analyses of variance on the effect of Alternaria eichhorniae spore concentration, Tween 80 concentration,type of solvent and their interaction on the damage severity score of water hyacinth.

\begin{tabular}{ll}
\hline Source of variance & F value \\
\hline Spore concentration (A) & $5.18^{* *}$ \\
Tween 80 concentration (B) & $9.36^{* *}$ \\
Type of solvent (C) & 0.09 \\
A x B & 0.64 \\
A x C & 1.06 \\
B x C & 0.64 \\
A x B x C & 0.15 \\
\hline
\end{tabular}

' = very significantly different at $99 \%$ confidence level.

Appendix 2. Analyses of variance on the effect of Neochetina bruchi numbers, concentration of Alternaria eichhorniae spore and their interaction on the damage severity score of water hyacinth due to pathogen, weevil and their combination under greenhouse conditions 14 days after weevil release.

\begin{tabular}{llll}
\hline \multicolumn{1}{c}{ Source of variance } & Pathogen & F value & Weevil \\
& & & Combination \\
& & $342.33^{* *}$ & $187.30^{* *}$ \\
Number of weevil pairs (A) & $36.50^{* *}$ & 2.33 & $38.95^{* *}$ \\
Spore concentration (B) & $173.75^{* *}$ & 1.56 & $4.17^{* *}$ \\
A x B & $4.58^{* *}$ & & \\
\hline
\end{tabular}

$=$ very significantly different at $99 \%$ confidence level

Appendix 3. Analyses of variance on the effect of Neochetina bruchi numbers, concentration of Alternaria eichhorniae spore and their interaction on the damage severity score of water hyacinth due to pathogen, weevil and their combination under greenhouse conditions 21 days after weevil release.

\begin{tabular}{llll}
\hline \multicolumn{1}{c}{ Source of variance } & Pathogen & F value & Weevil \\
& & & Combination \\
& & & \\
\hline Number of weevil pairs (A) & $24.58^{* *}$ & $491.60^{* *}$ & $140.70^{* *}$ \\
Spore concentration (B) & $239.95^{* *}$ & $8.80^{* *}$ & $50.66^{* *}$ \\
A x B & $3.08^{* *}$ & $2.43^{*}$ & $9.29^{* *}$ \\
& & & \\
\hline
\end{tabular}

*= significantly different at $95 \%$ confidence level **=

very significantly different at $99 \%$ confidence level 
Appendix 4. Analyses of variance on the effect of Neochetina bruchi numbers, concentration of Alternaria eichhomiae spore and their'interaction on the damage severity score of water hyacinth due to pathogen, weevil and their combination during dry season at 14 days after weevil release under field conditions.

\begin{tabular}{llll}
\hline \multicolumn{1}{c}{ Source of variance } & \multicolumn{1}{c}{ Pathogen } & \multicolumn{1}{c}{ F value } \\
& \multicolumn{1}{c}{ Weevil } & \multicolumn{1}{c}{ Combination } \\
\hline Number of weevil pairs (A) & 1.00 & $90.53^{* *}$ & $36.91^{* *}$ \\
Spore concentration (B) & $504.27^{* *}$ & 1.59 & $68.57^{* *}$ \\
A x B & 1.00 & 0.18 & $8.80^{* *}$ \\
& & & \\
\hline
\end{tabular}

*= very significantly different at 99\% confidence level.

Appendix 5. Analyses of variance on the effect of Neochetina bruchi numbers, concentration of Alternaria eichhomiae spore and their interaction on the damage severity score of water hyacinth due to pathogen, weevil and their combination during dry season at 21 days after weevil release under field conditions.

\begin{tabular}{llll}
\hline \multicolumn{1}{c}{ Source of variance } & \multicolumn{1}{c}{ Pathogen } & \multicolumn{1}{c}{$\begin{array}{l}\text { F value } \\
\text { Weevil }\end{array}$} & Combination \\
& & & \\
\hline Number of weevil pairs (A)) & 2.00 & $104.22^{* *}$ & $46.83^{* *}$ \\
Spore concentration (B) & $874.27^{* *}$ & $6.00^{*}$ & $112.32^{* *}$ \\
A x B & 2.00 & 1.11 & $14.97^{* *}$ \\
\hline
\end{tabular}

*= significantly different at $95 \%$ confidence level

$* *=$ very significantly different at $99 \%$ confidence level

Appendix 6. Analyses of variance on the effect of Neochetina bruchi numbers, concentration of Alternaria eichhomiae spore and their interaction on the damage severity score of water hyacinth due to pathogen, weevil and their combination during wet season at 14 days after weevil release under field conditions.

\begin{tabular}{lllc}
\hline Source of variance & & F value & \\
& Pathogen & Weevil & Combination \\
\hline Number of weevil pairs (A) & 2.00 & $80.73^{* *}$ & $75.00^{* *}$ \\
Spore concentration (B) & $486.00^{* *}$ & $9.80^{* *}$ & $216.00^{* *}$ \\
A x B & 2.00 & 1.27 & $5.00^{* *}$ \\
\hline
\end{tabular}

**= very significantly different at 99\% confidence level. 
Integrated use of Neochelina bruchi and Alternaria eichhomiae - Kasno et al.

Appendix 7. Analyses of variance on the effect of Neochetina bruchi numbers, concentration of Alternaria eichhomiae spore and their interaction on the damage severity score of water hyacinth due to pathogen, weevil and their combination during wet season at 21 days after weevil release under field conditions.

\begin{tabular}{llll}
\hline Source of variance & Pathogen & F value Weevil & Combination \\
& & & \\
\hline Number of weevil pairs (A) & 3.40 & $176.00^{* *}$ & $55.62^{* *}$ \\
Spore concentration (B) & $80.20^{* *}$ & $30.00^{* *}$ & $168.23^{* *}$ \\
A x B & 3.40 & $4.40^{*}$ & $5.77^{* *}$ \\
\hline
\end{tabular}

*= significantly different at $95 \%$ confidence level

$* *=$ very significantly different at $99 \%$ confidence level

Appendix 8. Analyses of variance on the effect of Neochetina bruchi numbers, concentration of Alternaria eichhomiae spore and their interaction on the change of water hyacinth wet weight.

\begin{tabular}{ll}
\hline \multicolumn{1}{c}{ Source of variance } & F value \\
\hline Number of weevil pairs (A) & $9.41^{* *}$ \\
Spore concentration (B) & $4.31^{*}$ \\
A x B & 0.48 \\
\hline
\end{tabular}

*= significantly different at $95 \%$ confidence level **=

very significantly different at $99 \%$ confidence level 